\title{
Pengaruh Terapi Aktivitas Kelompok Stimulasi Sensori: Menggambar terhadap Perubahan Tingkat Halusinasi pada Pasien Halusiansi di Ruang Rawat Inap Rumah Sakit Jiwa Daerah Jambi
}

\author{
Kamariyah*, Yuliana \\ Universitas Jambi \\ *Correspondence email: cocom2fahri@gmail.com
}

\begin{abstract}
Abstrak. Menurut data WHO (2017), terdapat sekitar 35 juta orang terkena depresi, 60 juta orang terkena bipolar, 21 juta terkena skizofrenia, serta 47,5 juta terkena dimensia. Adapun masalah keperawatan yang muncul dari diagnosis medis skizofrenia diantaranya adalah halusinasi.Berdasarkan data Rumah Sakit Jiwa di Indonesia, sekitar 70\% pasien yang menjalani perawatan di ruang rawat inap rumah sakit jiwa mengalami masalah keperawatan halusinasi. Data dari ruang rawat inap Rumah Sakit Jiwa Daerah Provinsi Jambi tahun 2018 dari 12 ruangan jumlah pasien yang mengalami masalah halusinasi sebanyak 4320 orang pasien, Adapun penatalaksanaan dari halusinasi adalah melalui penerapan asuhan keperawatan yang komprehensif yang terus menerus, disertai juga dengan terapi-terapi modalitas salah satu diantaranya adalah Terapi Aktivitas Kelompok. Tujuan Untuk mengetahui pengaruh Terapi Aktivitas Kelompok (TAK) stimulasi sensori: menggambar terhadap perubahan tingkat halusinasi pada pasien halusinasi di ruang rawat inap Rumah Sakit Jiwa Provinsi Jambi. Metodologi Penelitian Penelitian kuantitatif dengan desain penelitian Quasi Experiment yang menggunakan Pre - Test and Post - Test with Control Group dengan intervensi terapi stimulasi menggambar, pengumpulan data dilakukan dengan wawancara dan observasi. Uji statistik pada penelitian ini menggunakan Uji T Test Independent
\end{abstract}

Kata Kunci: Halusinasi; Terapi Aktivitas Kelompok Menggambar

\begin{abstract}
Indonesia According to WHO (2017) data, there are about 35 million people affected by depression, 60 million people are affected by bipolar, 21 million are affected by schizophrenia, and 47.5 million are affected by dementia. The nursing problems that arise from the medical diagnosis of schizophrenia include hallucinations. Based on data from Mental Hospitals in Indonesia, about $70 \%$ of patients undergoing treatment in inpatient wards of mental hospitals experience hallucinations nursing problems. Data from the inpatient room of the Jambi Provincial Mental Hospital in 2018 from 12 rooms the number of patients experiencing hallucinations was 4320 patients. The management of hallucinations is through the continuous application of comprehensive nursing care, accompanied by incorrect modality therapies. one of them is Group Activity Therapy. Objective: To determine the effect of Sensory Stimulation Group Activity Therapy (TAK) on changes in the level of hallucinations in hallucinating patients in the inpatient ward of the Jambi Province Mental Hospital. Research Methodology Quantitative research with a Quasi Experiment research design that uses Pre-Test and Post-Test with Control Group with drawing stimulation therapy intervention, data collection is done by interview and observation. The statistical test in this study used the Independent T Test
\end{abstract}

Keywords: Hallucinations; Group Activity Therapy Drawing

\section{PENDAHULUAN}

Menurut WHO sehat adalah keadaan keseimbangan yang sempurna baik fisik, mental dan sosial, tidak hanya bebas dari penyakit dan kelemahan. Kesehatan jiwa masih menjadi salah satu permasalahan kesehatan yang signifikan di dunia, termasuk di Indonesia. Menurut data WHO (2017), terdapat sekitar 35 juta orang terkena depresi, 60 juta orang terkena bipolar, 21 juta terkena skizofrenia, serta 47,5 juta terkena dimensia.

Study terbaru WHO di 14 negara menunjukkan bahwa pada negara-negara berkembang, sekitar 76-85\% kasus gangguan jiwa parah tidak dapat pengobatan apapun pada tahun utama (Hardian, 2008). Masalah kesehatan jiwa merupakan masalah kesehatan masyarakat yang demikian tinggi dibandingkan dengan masalah kesehatan lain yang ada dimasyarakat dari 150 juta populasi orang dewasa Indonesia (Yusup, 2015). berdasarkan data Kemenkes, ada 1,74 juta orang mengalami gangguan mental emosional. Sedangkan $4 \%$ dari jumlah tersebut terlambat berobat dan tidak tertangani akibat kurangnya layanan untuk penyakit kejiwaan ini (Kemenkes, 2018). Krisis ekonomi dunia yang semakin berat mendorong jumlah penderita gangguan jiwa di dunia, dan di indonesia terjadi peningkatan, diperkirakan sekitar 50 juta atau $25 \%$ dari jumlah penduduk Indonesia mengalami gangguan jiwa (Nurdwiyanti, 2008).

Berdasarkan data Rumah Sakit Jiwa di Indonesia, sekitar $70 \%$ pasien yang menjalani perawatan di ruang rawat inap rumah sakit jiwa mengalami masalah keperawatan halusinasi ${ }^{6}$. Data dari Buku Mutasi ruang rawat inap Rumah Sakit Jiwa Daerah Provinsi Jambi dari 12 ruangan jumlah pasien yang mengalami masalah halusinasi sebanyak 4320 orang pasien (Buku Mutasi RSJ, 2018).

Halusinasi adalah suatu gejala gangguan jiwa pada individu yang ditandai dengan perubahan sensori 
Kamariyah dan Yuliana, Pengaruh Terapi Aktivitas Kelompok Stimulasi Sensori: Menggambar terhadap Perubahan Tingkat Halusinasi pada Pasien Halusiansi di Ruang Rawat Inap Rumah Sakit Jiwa Daerah Jambi

persepsi: merasakan sensasi palsu berupa suara, penglihatan, perabaan pengecapan dan penghidu (Keliat, 2012). Halusinasi adalah hilangnya kemampuan manusia dalam membedakan rangsangan internal (pikiran) dan rangsanag eksternal (dunia luar). Sebagai contoh klien mengatakan mendengar suara padahal tidak ada orang yang berbicara (Kusumawati dan Hartono, 2010).

Tanda dan gejala yang dialami pasien dengan halusinasi antara lain bicara atau tertawa sendiri, marahmarah tanpa sebab,memalingkan muka ke arah telinga seperti mendengar sesuatu ,menutup telinga, menunjuknunjuk ke arah tertentu, ketakutan pada sesuatu yang tidak jelas, mencium sesuatu seperti sedang membaui bau-bauan tertentu,menutup hidung, sering meludah, muntah, dan menggaruk-garuk permukaan kulit. Individu yang mengalami halusinasi harus diarahkan pada respon perilaku yang adaptif melalui penerapan asuhan keperawatan yang komprehensif dan terus menerus, disertai juga dengan terapi-terapi modalitas seperti Terapi Aktivitas Kelompok (Keliat, 2019).

Berdasarkan hasil survey awal dan observasi yang dilakukan peneliti di ruangan rawat inap RSJD Provinsi Jambi pada tanggal 16 Februari didapatkan ada 240 orang pasien yang mengalami halusinasi yaitu diruangan Epsilon, Srikandi, Beta, Arimbi, Arjuna,yudistira, Gama, Shinta, Pega,Teta, Omega dan Delta. Berdasarkan wawancara langsung dengan perawat jaga pada ke-12 ruangan tersebut, pasien halusinasi sudah mendapatkan asuhan keperawatan sesuai dengan strategi pelaksanaan dari halusinasi, untuk pelaksanaan terapi aktivitas kelompok tergantung ruangan masing-masing, ada yang dilakukan 1 kali seminggu dan ada yang 1 kali dalam sebulan. Terapi stimulasi sensori pernah dilakukan pada beberapa pasien halusinasi, seperti terapi musik dan menonton, untuk terapi menggambar masih jarang dilakukan karena kurang tersedianya fasilitas menggambar, serta sudah banyak variasi terapi aktivitas kelompok lain yang diterapkan.

Aktivitas menggambar dapat membantu pasien dalam menyalurkan atau mengekspresikan perasaan, pemikiran, dan emosi yang selama ini mempengaruhi perilaku yang tidak di sadarinya, memberikan kegembiraan, hiburan, serta mengalihkan perhatian pasien pada dunianya sendiri untuk terlibat dalam kegiatan kelompok. Melalui aktivitas menggambar juga dapat membantu pasien untuk mengembangkan rasa percaya diri, belajar untuk mempercayai orang lain, serta memiliki kemampuan untuk berhubungan dengan orang lain. (Kompasiana, 2016)

\section{METODE}

Penelitian ini menggunakan desain Penelitian kuantitatif dengan desain penelitian Quasi Experiment yang menggunakan Pre - Test and Post - Test with Control Group dengan intervensi terapi stimulasi menggambar, pengumpulan data dilakukan dengan wawancara dan observasi. Uji statistik pada penelitian ini menggunakan Uji T Test Independent

\section{HASIL DAN PEMBAHASAN}

Penelitian ini dilakukan di RSJ Daerah Jambi dengan sampel sebanyak 16 responden untuk kelompok intervensi dan 16 responden untuk kelompok kontrol. Hasil penelitian Distribusi frekuensi responden pada kelompok intervensi berdasarkan umur terbanyak berusia 36-45 tahun (62,5\%), yang keseluruhannya berjenis kelamin laki-laki (100\%) dengan tingkat pendidikan paling banyak adalah SD sebanyak 7 responden $(43,8 \%)$. Selain itu, pekerjaan terbanyak adalah tidak bekerja $(56,3 \%)$, sebagian responden belum menikah $(37,5 \%)$, semua responden terdiagnosis medis skizofrenia (100\%), dan lama rawat responden terbanyak selama $<1$ bulan $(87,5 \%)$.

Tabel I. Gambaran Penilaian Kognitif, Psikomotor, Tanda dan Gejala Sebelum dan Setelah diberikan Terapi Stimulasi Sensori Menggambar pada Kelompok Intervensi

\begin{tabular}{lccccc}
\hline Variabel & Mean & SD & Min & Max & p-value \\
\hline $\begin{array}{l}\text { (Pre Test) sebelum diberi } \\
\text { perlakuan: menggambar }\end{array}$ & 32,38 & 8,229 & 16 & 42 & \\
$\begin{array}{l}\text { (Post Test) setelah diberi } \\
\text { perlakuan: menggambar }\end{array}$ & 36,19 & 7,296 & 17 & 42 & 0,004 \\
\hline
\end{tabular}

Berdasarkan tabel 1 dapat dilihat rata-rata (mean) penilaian kognitif,psikomotor dan tanda dan gejala pada kelompok intervensi sebelum diberikan perlakuan sebesar 32,38 dengan standar deviasi 8,229. Setelah diberikan perlakuan rata-rata (mean) penilaian kognitif, psikomotor dan tanda dan gejala halusinasi terjadi peningkatan menjadi 36,19 dengan standar deviasi 7,296. Hasil uji statistik didapatkan $p$-value $=0,004$ artinya terdapat penurunan tingkat halusinasi yang sangat signifikan atau bermakna pada saat sebelum dan setelah dilakukan TAK menggambar ( $p$-value $<\alpha 0,05)$. Peningkatan nilai mean yang terjadi menunjukkan bahwa terjadinya penurunan tingkat halusinasi.

Tabel 2. Gambaran Penilaian Kognitif, Psikomotor, Tanda dan Gejala Sebelum dan Setelah diberikan Terapi Stimulasi Sensori Menggambar pada Kelompok Kontrol

\begin{tabular}{lccccc}
\hline Variabel & Mean & SD & Min & Max & p-value \\
\hline $\begin{array}{l}\text { (Pre Test): Tanpa diberi } \\
\text { perlakuan: menggambar } \\
\text { (Post Test): Tanpa diberi }\end{array}$ & 27,94 & 12,678 & 4 & 42 & \\
perlakuan: menggambar & & & & & 0,118 \\
\hline
\end{tabular}

Berdasarkan tabel 2 dapat dilihat rata-rata (mean) pada observasi pertama (pre test) sebesar 27,94 dengan standar deviasi sebesar 12,678 skor rata-rata (mean) pada observasi kedua (post test) sebesar 20,31 dengan standar deviasi 7,040. Hasil uji statistik didapatkan $p$ value $=0,118$ artinya tidak terdapat perbedaan antara pre test dan post test. 
Kamariyah dan Yuliana, Pengaruh Terapi Aktivitas Kelompok Stimulasi Sensori: Menggambar terhadap Perubahan Tingkat Halusinasi pada Pasien Halusiansi di Ruang Rawat Inap Rumah Sakit Jiwa Daerah Jambi

Tabel 3. Pengaruh Terapi Aktivitas Kelompok (TAK) Stimulasi Sensori Menggambar Terhadap Perubahan Tingkat Halusinasi

\begin{tabular}{|c|c|c|c|c|c|}
\hline Variabel & Mean & $\mathrm{N}$ & $\begin{array}{c}\text { Std. Error } \\
\text { Mean }\end{array}$ & $\begin{array}{c}\text { Std. } \\
\text { Deviation }\end{array}$ & $\begin{array}{c}\mathrm{p}- \\
\text { value }\end{array}$ \\
\hline $\begin{array}{l}\text { Post Test: Kelompok } \\
\text { Intervensi }\end{array}$ & 36,19 & 16 & 1,696 & 6,784 & \multirow[t]{2}{*}{0,000} \\
\hline $\begin{array}{l}\text { Post Test : Kelompok } \\
\text { Kontrol }\end{array}$ & 20,31 & 16 & 1,760 & 7,040 & \\
\hline
\end{tabular}

Tabel 3 menunjukkan bahwa hasil uji statistik $p$ value $=0,000<0,05$ artinya kelompok yang diberikan Terapi Aktivitas Kelompok (TAK) menggambar lebih efektif dibandingkan yang tidak, dan dapat disimpulkan terdapat pengaruh terapi aktivitas kelompok mengambar terhadap perubahan tingkat halusinasi

\section{Pembahasan}

Nilai rata-rata (mean) pada kelompok intervensi yaitu 32,38 , dengan nilai maksimal 42 dan nilai minimal 16. Setelah diberikan perlakuan rata-rata (mean) penilaian kognitif, psikomotor dan tanda dan gejala halusinasi terjadi peningkatan menjadi 36,19 dengan standar deviasi 7,296. Hasil uji statistik didapatkan $p$ value $=0,004$ artinya terdapat penurunan tingkat halusinasi yang sangat signifikan atau bermakna pada saat sebelum dan setelah dilakukan TAK menggambar ( $p$-value $<\alpha 0,05)$. Peningkatan nilai mean yang terjadi menunjukkan bahwa terjadinya penurunan tingkat halusinasi. Hasil penelitian didapatkan bahwa sebelum diberikan TAK menggambar (pre test), dari 16 responden ada 4 responden pada kelompok intervensi pada saat pre test halusinasinya tidak muncul yang dapat dilihat dari lembar kuisioner tanda gejala halusinasi dengan 3 aspek penilaian yaitu kognitif, psikomotor, tanda dan gejala halusinasi.

Berdasarkan hasil wawancara dari penilaian kognitif didapatkan $56,3 \%$ responden tidak bisa menyebutkan dosis obat, 37,5\% tidak bisa menyebutkan jenis obat, dan akibat berhenti minum obat. Sedangkan berdasarkan observasi 43,8\% responden belum mampu mengajak pasien lain untuk bercakap- cakap, 37,5\% responden belum mampu melakukan latihan menghardik, $31,3 \%$ responden belum mampu memperagakan cara menghardik, mengontrol halusinasi, dan memperagakan cara meminta obat.

Berdasarkan hasil observasi psikomotor yang timbul pada saat dilakukan pre test klien tampak berbicara sendiri sebanyak 62,5\%, klien tampak tertawa sendiri sebanyak 56,3\%, klien seolah mendengar sesuatu sebanyak $75 \%$, dan klien tampak melakukan tindakan tanpa stimulus eksternal sebanyak $62,5 \%$ pada kelompok intervensi. Sedangkan pada saat post test klien tampak berbicara sendiri sebanyak 43,8\%, klien tampak tertawa sendiri sebanyak 43,8\%, klien seolah mendengar sesuatu sebanyak $43,8 \%$ dan klien tampak melakukan tindakan tanpa stimulus eksternal sebanyak $43,8 \%$.
Hasil observasi psikomotor didapatkan presentase sebelum dan sesudah terapi aktivitas kelompok menggambar $43,8 \%$ menjadi $37,5 \%$ responden belum mampu mengajak responden untuk bercakap- cakap, $37,5 \%$ menjadi $25,0 \%$ responden belum mampu melakukan latihan menghardik, 31,3\% menjadi $12,5 \%$ responden belum mampu memperagakan cara menghardik, sedangkan untuk mengontrol halusinasi belum terjadi perubahan presentase, sedangkan untuk memperagakan cara meminta obat terjadi perubahan dari $31,3 \%$ menjadi $12,5 \%$ responden belum mampu memperagakan cara menghardik, sedangkan untuk mengontrol halusinasi belum terjadi perubahan presentase, adapun untuk memperagakan cara meminta obat terjadi perubahan dari $31,3 \%$ menjadi $12,5 \%$.

Hasil penelitian yang didapat menunjukan sebelum diberikan terapi aktivitas kelompok menggambar tanda dan gejala halusinasi yang dialami pasien halusinasi sebagian besar berada dalam kategori ringan. dikarenakan sebagian besar responden $(85 \%)$ sudah mendapatkan terapi individu dari perawat ruangan, halusinasi menyebabkan pasien mengalami ketidakmampuan atau kerusakan dalam hubungan sosialnya sehingga pasien hidup dialamnya sendiri, berinteraksi dengan pikirannya yang diciptakan sendiri, seolah-olah semuanya menjadi sesuatu yang nyata sehingga responden tidak dapat mengalihkan dan mengontrol halusinasi yang dialaminya.

halusinasi adalah suatu tanggapan dari panca indera tanpa adanya rangsangan (stimulus) eksternal, Halusinasi merupakan gangguan persepsi dimana pasien mempersepsikan sesuatu yang sebenarnya tidak terjadi. Ada lima jenis halusinasi yaitu pendengaran, penglihatan, penghidu, pengecapan dan perabaan. Halusinasi pendengaran merupakan jenis halusinasi yang paling banyak ditemukan dan terjadi pada $70 \%$ pasien,kemudian halusinasi penglihatan $20 \%$, dan sisanya $10 \%$ adalah halusinasi penghidu, pengecapan dan perabaan (Iyus, 2007).

Sedangkan pada pasien yang sehat mampu mengidentifikasi dan menginterprestasikan stimulasi berdasarkan informasi yang diterima melalui panca indra (Keliat, 2011). hal ini dapat dilihat dari analisis kuesioner terjadi perubahan presentase antara pre test dan post test antara penilaian kognitif, psikomotor, tanda dan gejala Sebelum dan setelah TAK Menggambar diberikan.

Berdasarkan hasil komponen penilaian rata-rata (mean) pada observasi pertama (pre test) sebesar 27,94 dengan standar deviasi sebesar 12,678 skor rata-rata (mean) pada observasi kedua (post test) sebesar 20,31 dengan standar deviasi 7,040. Hasil uji statistik didapatkan $p$-value $=0,118$ artinya tidak terdapat perbedaan antara pre test dan post test. Berdasarkan observasi tanda dan gejala pada saat pre test pada kelompok kontrol klien tampak berbicara sendiri sebanyak 37,5\%, klien tampak tertawa sendiri sebanyak 
$31,3 \%$, klien seolah mendengar sesuatu sebanyak $43,8 \%$ dan klien tampak melakukan tindakan tanpa stimulus eksternal sebanyak $43,8 \%$.

Hasil wawancara pada saaat pre test untuk penilaian kognitif 50\% pasien tidak bisa menyebutkan akibat berhenti minum obat, $50 \%$ tidak bisa menyebutkan manfaat melakukan aktivitas,50\% tidak mampu menjelaskan cara bercakap- cakap dengan orang lain, 43,8\% responden tidak mampu menyebutkan dosis obat, manfaat obat, dan hal yang dirasakan setelah minum obat.

Berdasarkan observasi $50 \%$ responden belum mampu melakukan latihan bercakap- cakap,50\% responden belum mampu mengajak orang lain bercakap - cakap, 50\% responden belum mampu melukukan aktivitas saat halusinasi muncul, 43,8\% responden belum mampu melakukan kegiatan yang telah dilatih sesuai jadwal.

Hasil wawancara sesudah terapi aktivitas kelompok: menggambar didapatkan hasil tidak ada perbedaan antara pre test dan post test.dapat lihat dari analisis kuesioner yaitu klien masih berbicara sendiri sebelum pre test $37,5 \%$ setelah post test meningkat menjadi $43,8 \%$, Hasil penelitian menunjukkan bahwa TAK stimulasi sensori menggambar berpengaruh dapat dilihat dari hasil uji statistik $p$-value $=0,000<0,05$ artinya kelompok yang diberikan Terapi Aktivitas Kelompok (TAK) menggambar lebih efektif dibandingkan yang tidak, dan dapat disimpulkan terdapat pengaruh terapi aktivitas kelompok mengambar terhadap perubahan tingkat halusinasi. Sejalan dengan penelitian yang dilakukan (Iwayan, 2013) di RSJ Provinsi Bali pada pasien halusinasi, hasil uji satistik paired T-test menunjukan bahwa ada pengaruh yang sangat signifikan pemberian terapi okupasi menggambar terhadap peruahan tingkat halusinasi pada pasien skofrenia dengan nilai $\mathrm{p}=.000(\mathrm{p}<0,01)$.

\section{SIMPULAN}

Terapi aktivitas kelompok menggambar bisa menurunkan tingkatan halusinasi pada pasien halusinasi. Terapi aktivitas kelompok menggambar terbukti dapat merubah tingkat halusinasi, sehingga dapat dijadikan sebagai salah satu terapi modalitas bagi pasien gangguan jiwa khususnya dengan masalah keperawatan halusinasi.

\section{Saran}

Bagi RSJD Provinsi Jambi Terapi aktivitas kelompok menggambar terbukti dapat menurunkan tingkat halusinasi, sehingga dapat dijadikan sebagai salah satu terapi modalitas bagi pasien gangguan jiwa khususnya dengan masalah keperawatan halusinasi. Sebaiknya terapi menggambar ini dilakukan secara rutin untuk membantu dalam proses penyembuhan pasien. Bagi Program Studi Keperawatan Program Studi Keperawatan dapat menggunakan hasil penelitian ini sebagai tambahan pengetahuan dan bahan referensi dalam upaya memperkaya ilmu keperawatan jiwa. Bagi Peneliti Selanjutnya Hasil penelitian ini dapat dijadikan sebagai bahan informasi terkait pengaruh terapi aktivitas kelompok sensori menggambar terhadap perubahan tingkat halusinasi pada pasien halusinasi dan sebagai data pembanding untuk penelitian selanjutnya dengan kasus atau terapi yang berbeda dalam penelitian ini.

\section{DAFTAR PUSTAKA}

Buku mutasi rawat inap Rumah Sakit Jiwa Daerah Provinsi Jambi pada tahun 2018.

World Health Organization, 2017. Tentang gangguan mental

Hardian, 2008. Buku Ajar Keperawatan Jiwa. Jakarta: EGC

Iwayan, Ni Kadek, I ketut, 2013. Terapi Okupasi Aktivitas Menggambar Terhadap Perubahan Halusinasi Pada Pasien Skiofrenia

Keliat,B.A,dkk, 2019. Asuhan Keperawatan Jiwa. Jakarta: EGC

Keliat, B.A. dan Akemat, 2012. Keperawatan Jiwa Terapi Aktivitas Kelompok. Jakarta: EGC. 2004 (Cetakan 2012).

Keliat, B.A,dkk, 2011. Keperawatan Kesehatan Jiwa Komunitas.Jakarta: EGC

Kementerian Kesehatan Republik Indonesia. Hasil Utama Riskesdas 2018. Di unduh darihttp://www.depkes.go.id/resources/download/i nfo terkini/materi_rakorpop_2018/Hasil\%20Riskesdas $\% 202018 . p d f$

Kompasiana. 2012. Aktivitas Seni Bagi Penderita Gangguan Jiwa. 21 Februari 2016. Diakses 12 Januari 2018. Di unduh dari https://www.kompasiana.com/adryanas85/56c91e e85b7b61320598e672/menggambar-sebagaiterapi-untuk-penderita-gangguan-jiwa

Kusumawati, F \& Hartono, Y, 2010. Buku ajar keperawatan jiwa. Malang: Salemba Medika

Nurdwiyanti, 2008. Pedoman Penanganan pada Gangguan Jiwa Manajemen

Yusup, 2015. Buku Ajar Keperawatantan Kesehatan Jiwa. Jakarta: Salemba Medika

Yosep, Iyus, 2007. Keperawatan Jiwa. Bandung: Refika Aditama 